\title{
Cancer is associated with severe disease in COVID-19 patients: a systematic review and meta-analysis
}

\author{
Richard Ofori-Asenso ${ }^{1,2}$, Oyepeju Ogundipe ${ }^{3}$, Akosua Adom Agyeman ${ }^{4}$, Ken Lee Chin ${ }^{1,5}$, Mohsen Mazidi ${ }^{6}$, Zanfina Ademi ${ }^{1}$, \\ Marie Louise De Bruin² and Danny Liew ${ }^{1}$
}

\begin{abstract}
${ }^{1}$ Department of Epidemiology and Preventive Medicine, Monash University, Melbourne, Victoria, VIC 3004, Australia
${ }^{2}$ Copenhagen Centre for Regulatory Science, Department of Pharmacy, University of Copenhagen, 2100 Copenhagen, Denmark

${ }^{3}$ Cardiac Renal and Vascular Associates PC, Jackson, MS 39204, USA

${ }^{4}$ Centre for Medicine Use and Safety, Monash Institute of Pharmaceutical Sciences, Monash University, Victoria, VIC 3052, Australia

${ }^{5}$ Melbourne Medical School, University of Melbourne, Victoria, VIC 3010, Australia

${ }^{6}$ Department of Twin Research and Genetic Epidemiology, Kings College London, London, SE1 7EH, UK
\end{abstract}

\section{Abstract}

Cancer patients are vulnerable to complications of respiratory viruses. This systematic review and meta-analysis sought to examine the prevalence of cancer and its association with disease severity in patients with novel coronavirus disease 2019 (COVID-19). Searches were performed in MEDLINE, EMBASE and ScienceDirect from their inception until 28 April 2020. Severe disease was considered to encompass cases resulting in death or as defined by the primary study authors. Meta-analysis was performed using random-effect models. We included 20 studies involving 32,404 patients from China, the United Kingdom, the United States, Italy, Singapore, Thailand, France, India and South Korea. The pooled prevalence of cancer was 3.50\% (95\% confidence interval (CI) 1.70 to 5.80). The pooled prevalence was not moderated by study mean age, proportion of females or whether the study was conducted in/outside of China. Patients with cancer were more likely to experience severe COVID-19 disease compared to patients without cancer (pooled risk ratio $1.76,95 \% \mathrm{Cl} 1.39$ to 2.23). Our findings reiterate the need for additional precautionary measures to ensure that patients with cancer are not exposed to COVID-19, and if they become infected, extra attention should be provided to minimise their risk of adverse outcomes.

Keywords: COVID-19, coronavirus, SARS, pandemic

\section{Inroduction}

The world is battling an immense threat from novel corona virus disease 2019 (COVID19). As of 28 April 2020, more than 3.1 million confirmed COVID-19 cases had been reported from over 150 countries, among whom over 220,000 had died [1]. Most COVID19-related deaths have been attributed to multiple organ failure in older or comorbid individuals [2].

Correspondence to: Richard Ofori-Asenso Email: Richard.ofori-asenso@monash.edu

ecancer 2020, 14:1047

https://doi.org/10.3332/ecancer.2020.1047

Published: $18 / 05 / 20$

Received: 10/04/2020

Publication costs for this article were supported by ecancer (UK Charity number 1176307).

Copyright: (c) the authors; licensee ecancermedicalscience. This is an Open Access article distributed under the terms of the Creative Commons Attribution License (http:// creativecommons.org/licenses/by/3.0), which permits unrestricted use, distribution, and reproduction in any medium, provided the original work is properly cited. 
A recent meta-analysis estimated that $2 \%$ of patients with COVID-19 had cancer [3]. However, the analysis included only data from China and did not evaluate the association of cancer with severe COVID-19 disease. Cancer patients may be more susceptible to COVID-19 than healthy individuals due to their high immunosuppressive burden caused by the cancer and anticancer treatments [4]. Improved understanding of the burden of cancer in COVID-19 patients may help to guide clinical management. Hence, in this study, we aimed to estimate the prevalence of cancer among COVID-19-infected patients as well as ascertain the association between cancer and disease severity.

\section{Methods}

A systematic review was performed in accordance with the recommendations outlined in the PRISMA statement [5] and the Cochrane Handbook [6]. We searched MEDLINE, EMBASE and ScienceDirect using the terms 'comorbidities' or 'clinical characteristics' or 'epidemiological' and 'COVID-19' or 'Coronavirus' or '2019-nCoV' or 'SARS-CoV-2' or '2019 novel coronavirus' (Supplemental Table S1). The search was last updated on April 28, 2020. Further searches were also performed via the websites of the World Health Organization (WHO) and key public health institutions in some of the most affected countries (Supplementary Table S2) [1]. The reference lists of identified studies were also screened for additional papers. Two reviewers (O.O and R.O) performed article screening and any disagreements were resolved via consensus. Severe disease was considered to encompass cases resulting in death [7] or as defined by the study authors [7]. The quality of individual studies was evaluated using the Newcastle-Ottawa Scale (NOS) for non-randomized studies [8]. For each study, two reviewers (R.O and O.O) independently collected data, including author details, country (region), mean age, proportion of females, and data on prevalence and disease severity. We excluded studies based on family clusters, those focusing solely on deceased individuals and case series involving $<10$ patients or only children. Moreover, reviews, commentaries and editorials were excluded. Furthermore, because a national-based study in China was published with data up to February 11, 2020, we excluded all sub-national studies in China that recruited only patients up until that date. However, if a study based in China recruited patients beyond this date, they were included. Also, if studies from the same region or hospital recruiting patients over the period were present, we selected the report with the larger sample size or more detailed data.

Meta-analysis of prevalence was performed using Freeman-Tukey double arcsine transformation to adjust for variance instability [9]. Owing to anticipated between-study heterogeneity, random-effect model was used [6]. Furthermore, pooled risk ratios (RRs) and corresponding 95\% confidence intervals ( $\mathrm{Cls}$ ) were derived to characterise the association between cancer and the occurrence of severe disease. Betweenstudy heterogeneity was quantified using the $I^{2}$ statistic [5]. A leave-one-out sensitivity analyses assessed the stability of pooled estimates. We applied meta-regression to determine whether the pooled prevalence was moderated by the age of study participants, gender distribution or location of the study (in/outside of China). All analyses were conducted using Stata SE software version 16 (StataCorp, TX, USA). A two-tailed $p$-value of $<0.05$ was considered as significant.

\section{Results}

The electronic searches retrieved 2,410 citations. Following removal of duplicates and screening of titles and abstracts, 94 articles were selected for full text evaluation. Twenty articles were retained after full-text assessment (Figure 1) [10-29]. The included studies were from China $(n=10)$, the United Kingdom $(n=2)$, South Korea $(n=1)$, the United States $(n=2)$, Italy $(n=1)$, Singapore $(n=1)$, India $(n=1)$, France $(n$ $=1$ ) and Thailand $(n=1)$. The studies involved a total of 32,404 patients. The mean age ranged from 40.3 to 75.0 years and $18.0 \%$ to $67.1 \%$ of the patients were females (Table 1).

Across the studies, the reported prevalence of cancer ranged from $0 \%$ to $21.0 \%$. The pooled prevalence was $3.5 \%\left(95 \% \mathrm{Cl} 1.7\right.$ to $5.8 \%, I^{2}=$ 97.4\%) (Figure 2). A leave-one-out sensitivity analysis did not change the results (point estimate ranged from $3 \%$ to $4 \%$ ). There was no significant moderation of the pooled prevalence by the participants' mean age (coefficient $=0.0034, p=0.247$ ), proportion of females (coefficient $=0.0006, p=0.557$ ) or being conducted in/outside of China (coefficient $=-0.009, p=0.795$ ). Across six studies involving 22,046 patients, those with cancer were more likely to experience severe disease compared to patients without cancer (pooled risk ratio $\left(R_{\text {pooled }}\right) 1.76,95 \%$ $\mathrm{Cl} 1.39$ to $2.23, I^{2}=20.9 \%$ ) (Figure 3). A leave-one-out analyses did not change the results (the estimates ranged from $\mathrm{RR}_{\text {pooled }} 1.66(95 \% \mathrm{Cl}$ 1.27 to 2.17$)$ to $1.82(95 \% \mathrm{Cl} 1.26$ to 2.64$))$. 


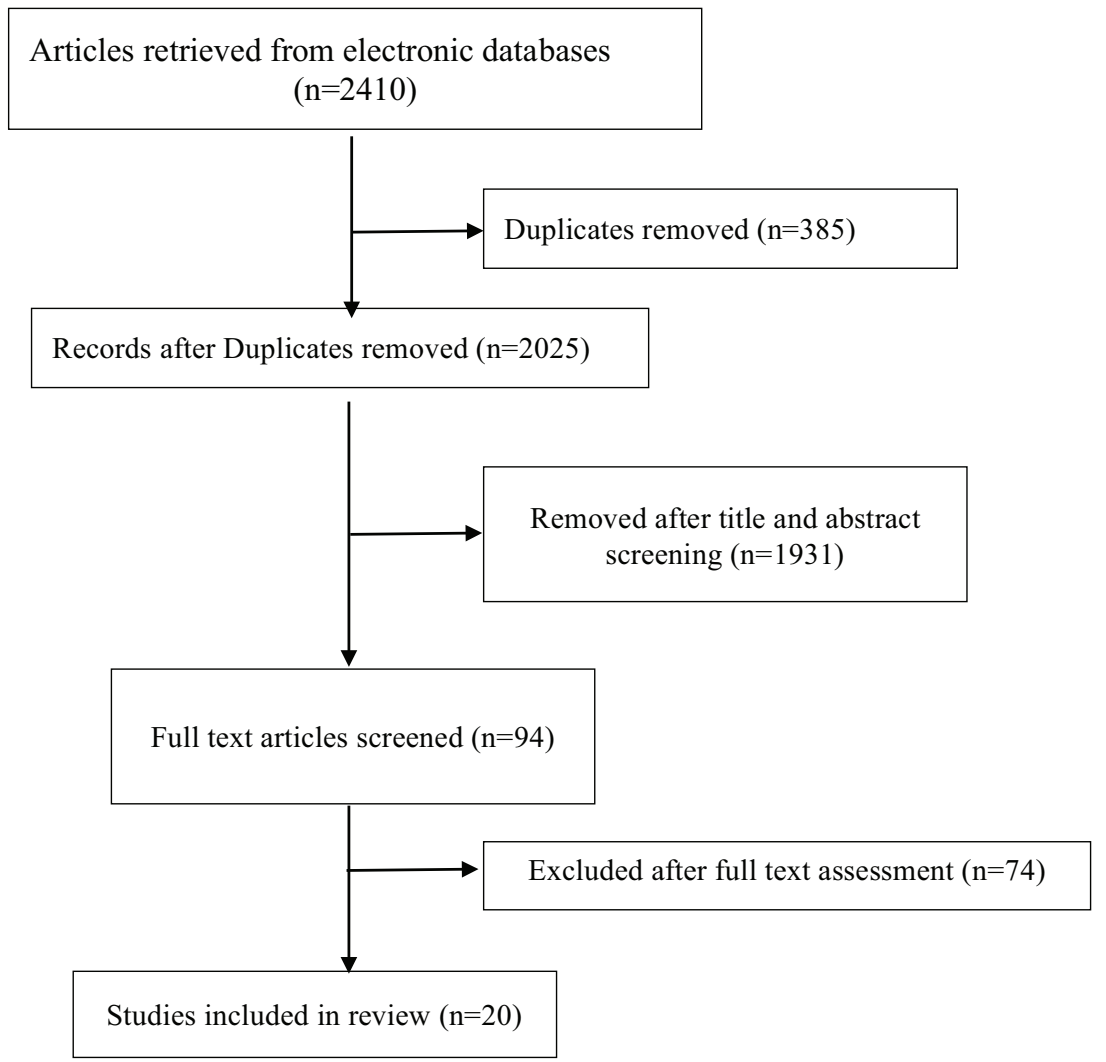

Figure 1. PRISMA flow chart of studies selection process.

Table 1. Characteristics of included studies.

\begin{tabular}{|c|c|c|c|c|c|c|c|c|c|c|}
\hline \multirow[b]{2}{*}{$\begin{array}{c}\text { Study } \\
\text { No. }\end{array}$} & \multirow[b]{2}{*}{ Author details** } & \multirow[b]{2}{*}{$\begin{array}{c}\text { Country } \\
\text { (location) }\end{array}$} & \multirow[b]{2}{*}{ Hospital } & \multirow[b]{2}{*}{$\begin{array}{l}\text { Last follow } \\
\text { up }\end{array}$} & \multirow[b]{2}{*}{$\begin{array}{l}\text { Sample } \\
\text { size }\end{array}$} & \multirow[b]{2}{*}{$\begin{array}{l}\text { Mean } \\
\text { age }\end{array}$} & \multirow{2}{*}{$\begin{array}{c}\% \\
\text { Female }\end{array}$} & \multirow{2}{*}{$\begin{array}{l}\text { No. (\%) } \\
\text { with } \\
\text { cancer }\end{array}$} & \multicolumn{2}{|c|}{ No. (\%) severe disease ${ }^{a}$} \\
\hline & & & & & & & & & $\begin{array}{c}\text { Cancer } \\
\text { patients }\end{array}$ & Non-cancer \\
\hline 1. & $\begin{array}{l}\text { COVID-19 National } \\
\text { Emergency Response } \\
\text { Center, Epidemiology } \\
\text { and Case Manage- } \\
\text { ment Team, Korea } \\
\text { Centers for Disease } \\
\text { Control and Preven- } \\
\text { tion [10] }\end{array}$ & South Korea & $\begin{array}{l}\text { Korea Centers for } \\
\text { Disease Control } \\
\text { and Prevention }\end{array}$ & $\begin{array}{l}\text { February } \\
14,2020\end{array}$ & 28 & 42.6 & 46.4 & $1(3.6)$ & - & - \\
\hline 2. & ICNARC [11] & $\begin{array}{l}\text { United } \\
\text { Kingdom }\end{array}$ & $\begin{array}{l}\text { England, Wales } \\
\text { and Northern } \\
\text { Ireland critical } \\
\text { care units }\end{array}$ & $\begin{array}{l}\text { March 26, } \\
2020\end{array}$ & $775^{a}$ & 60.2 & 29.1 & $12(1.2)$ & - & - \\
\hline 3. & Wu et al [12] & China (Jiangsu) & $\begin{array}{l}3 \text { grade IIIA } \\
\text { hospitals }\end{array}$ & $\begin{array}{l}\text { February } \\
14,2020\end{array}$ & 80 & 46.1 & 51.3 & $1(1.3)$ & - & - \\
\hline
\end{tabular}


Table 1. Characteristics of included studies. (Continued)

\begin{tabular}{|c|c|c|c|c|c|c|c|c|c|c|}
\hline 4. & $\begin{array}{l}\text { The Novel Corona- } \\
\text { virus Pneumonia } \\
\text { Emergency Response } \\
\text { Epidemiology Team } \\
\text { [13] }\end{array}$ & China & Nationwide & $\begin{array}{l}\text { February } \\
11,2020\end{array}$ & $20982^{b}$ & - & 48.6 & $107(0.5)$ & $6(5.6)$ & 400 (1.9) \\
\hline 5. & Zhu et al [14] & $\begin{array}{l}\text { China (Outside } \\
\text { of Hubei) }\end{array}$ & $\begin{array}{l}\text { Anhui Province } \\
\text { ED }\end{array}$ & $\begin{array}{l}\text { February } \\
20,2020\end{array}$ & 32 & 46.0 & 53.0 & $2(6.3)$ & - & - \\
\hline 6. & Sun et al [15] & Singapore & $\begin{array}{l}\text { National } \\
\text { Centre for Infec- } \\
\text { tious Diseases }\end{array}$ & $\begin{array}{l}\text { February } \\
16,2020\end{array}$ & 54 & 42.0 & 46.3 & $0(0.0)$ & - & - \\
\hline 7. & Chen et al [16] & China (Wuhan) & Tongji Hospital & $\begin{array}{l}\text { February } \\
28,2020\end{array}$ & 274 & 62.0 & 38.0 & $7(3.0)$ & $5(71.4)$ & $108(40.4)$ \\
\hline 8. & Guo et al [17] & China (Wuhan) & $\begin{array}{l}\text { No. } 7 \text { Hospital of } \\
\text { Wuhan }\end{array}$ & $\begin{array}{l}\text { February } \\
23,2020\end{array}$ & 187 & 58.5 & 51.3 & $13(7.0)$ & - & - \\
\hline 9. & McMichael et al [18] & $\begin{array}{l}\text { US (Washing- } \\
\text { ton) }\end{array}$ & $\begin{array}{l}\text { skilled nursing } \\
\text { facility in King } \\
\text { County }\end{array}$ & $\begin{array}{l}\text { March 18, } \\
2020\end{array}$ & 167 & 72.0 & 67.1 & $15(9.0)$ & - & - \\
\hline 10. & Gupta et al [19] & $\begin{array}{l}\text { India (New } \\
\text { Delhi) }\end{array}$ & $\begin{array}{l}\text { Sarfdarjung } \\
\text { hospital }\end{array}$ & $\begin{array}{l}\text { March 19, } \\
2020\end{array}$ & 21 & 40.3 & 33.3 & $0(0.0)$ & - & - \\
\hline 11. & Klopfenstein et al [20] & France & NFC hospital & $\begin{array}{l}\text { March 17, } \\
2020\end{array}$ & 54 & 47.0 & 67.0 & $2(4.0)$ & - & - \\
\hline 12. & Richardson et al [21] & US (New York) & $\begin{array}{l}\text { Northwell Health } \\
\text { hospitals }\end{array}$ & $\begin{array}{l}\text { April 4, } \\
2020\end{array}$ & 5700 & 63.0 & 39.7 & $320(6.0)$ & - & - \\
\hline 13. & Pan et al [22] & China (Hubei) & $\begin{array}{l}\text { Wuhan Hanan } \\
\text { Hospital, Wuhan } \\
\text { Union Hospital, } \\
\text { and Huanggang } \\
\text { Central Hospital }\end{array}$ & $\begin{array}{l}\text { March 18, } \\
2020\end{array}$ & $\begin{array}{l}204 \\
\text { (diges- } \\
\text { tive } \\
=103 \text { ) }\end{array}$ & 52.9 & 52.5 & $13(6.37)$ & $4(50.0)^{c}$ & $33(34.7)^{c}$ \\
\hline 14. & Pongpirul et al [23] & Thailand & $\begin{array}{l}\text { Bamrasnaradura } \\
\text { Infectious Dis- } \\
\text { eases Institute }\end{array}$ & $\begin{array}{l}\text { January 31, } \\
2020\end{array}$ & 11 & 61.0 & 45.5 & $0(0)$ & - & - \\
\hline 15. & Feng et al [24] & $\begin{array}{l}\text { China } \\
\text { (Multicentre) }\end{array}$ & $\begin{array}{l}\text { Jinyintan Hos- } \\
\text { pital in Wuhan, } \\
\text { Shanghai Public } \\
\text { Health Clinical } \\
\text { Center in Shang- } \\
\text { hai and Tongling } \\
\text { People's Hospital } \\
\text { in Anhui Province }\end{array}$ & $\begin{array}{l}\text { February } \\
15,2020\end{array}$ & 476 & 53.0 & 43.1 & $12(2.5)$ & $7(58.3)$ & $117(25.2)$ \\
\hline 16. & Yu et al [5] & $\begin{array}{l}\text { China (Wu- } \\
\text { han) }\end{array}$ & $\begin{array}{l}\text { Zhongnan Hos- } \\
\text { pital of Wuhan } \\
\text { University }\end{array}$ & $\begin{array}{l}\text { February } \\
17,2020\end{array}$ & 1524 & - & - & $12(0.79)$ & - & - \\
\hline 17. & Grasselli et al [26] & $\begin{array}{l}\text { Italy (Lom- } \\
\text { bardy) }\end{array}$ & 72 hospitals & $\begin{array}{l}\text { March 18, } \\
2020\end{array}$ & $1591^{a}$ & 63.0 & 18.0 & $81(8.0)$ & - & - \\
\hline
\end{tabular}


Table 1. Characteristics of included studies. (Continued)

\begin{tabular}{|c|c|c|c|c|c|c|c|c|c|c|}
\hline 18. & Wang et al [27] & China (Wuhan) & $\begin{array}{l}\text { Renmin Hospital } \\
\text { of Wuhan Uni- } \\
\text { versity }\end{array}$ & $\begin{array}{l}\text { February } \\
13,2020\end{array}$ & 116 & 54 & 42.2 & 12 (10.3) & $11(91.6)$ & $58 / 104$ \\
\hline 19. & Chu et al [28] & $\begin{array}{l}\text { China (Wen- } \\
\text { zhou city) }\end{array}$ & $\begin{array}{l}\text { First Affiliated } \\
\text { Hospital of Zheji- } \\
\text { ang University }\end{array}$ & $\begin{array}{l}\text { February } \\
23,2020\end{array}$ & $33^{a}$ & 65.2 & 33.3 & $1(3.0)$ & - & - \\
\hline 20. & Tomlins et al [29] & UK (England) & $\begin{array}{l}\text { North Bristol } \\
\text { NHS Trust }\end{array}$ & $\begin{array}{l}\text { March 30, } \\
2020\end{array}$ & 95 & 75.0 & 37.0 & $20(21)$ & $3(15.0)$ & $17(22.7)$ \\
\hline
\end{tabular}

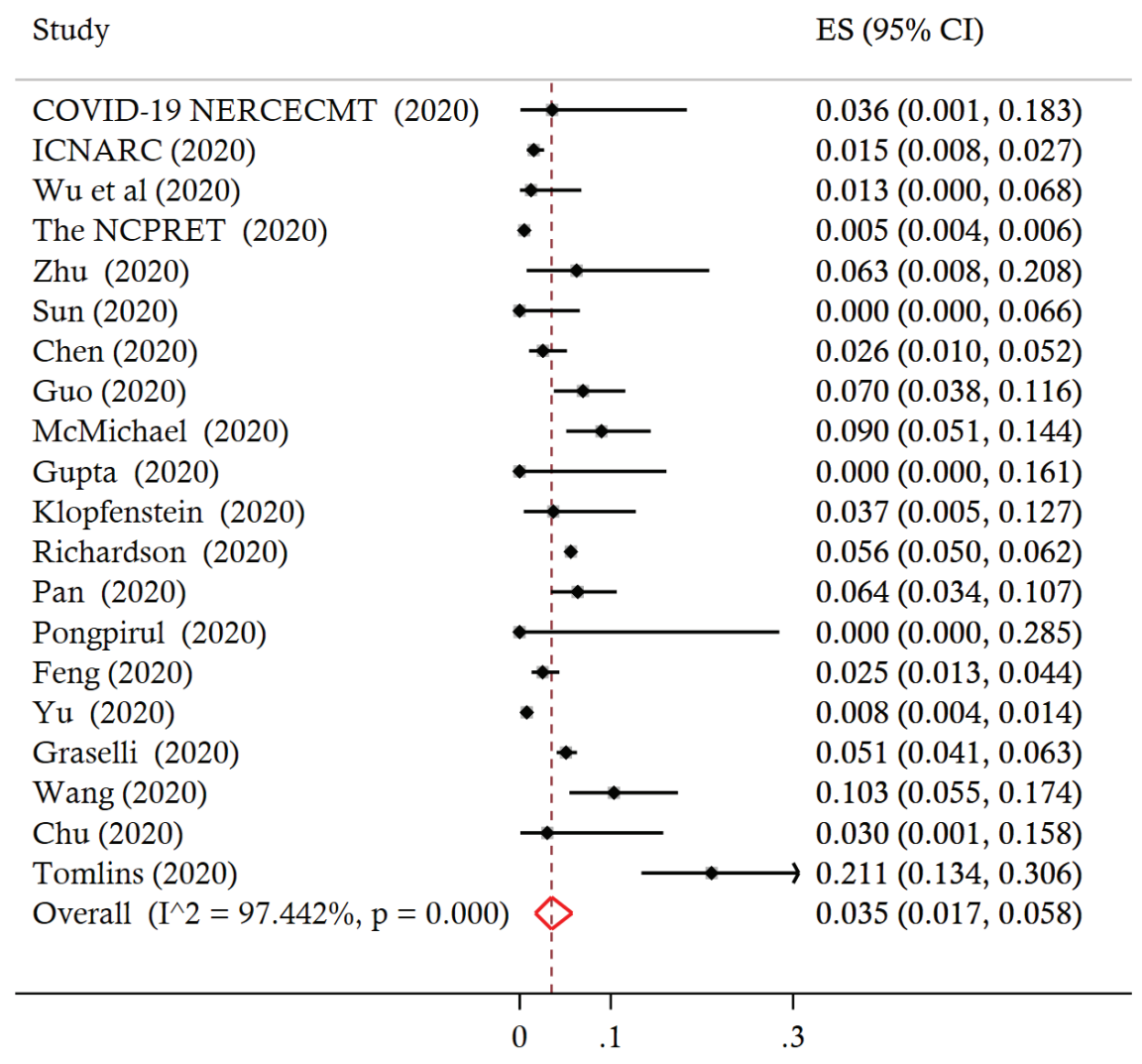

Figure 2. Forest plot of prevalence of cancer among patients infected with COVID-19. 


\begin{tabular}{|c|c|}
\hline The NCETP (2020) & 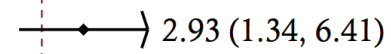 \\
\hline Chen (2020) & $1.77(1.08,2.88)$ \\
\hline Pan (2020) & $1.44(0.68,3.03)$ \\
\hline Feng (2020) & $2.31(1.40,3.83)$ \\
\hline Wang (2020) & $1.64(1.29,2.09)$ \\
\hline Tomlins (2020) & $0.66(0.22,2.04)$ \\
\hline Overall $(\mathrm{I}$-squared $=20.9 \%, \mathrm{p}=0.276)$ & $1.76(1.39,2.23)$ \\
\hline NOTE: Weights are from random effects analysis & \\
\hline
\end{tabular}

Figure 3. Forest plot of association between cancer and severe disease among COVID-19 patients.

\section{Discussion}

The results of our meta-analysis suggest a low prevalence of cancer among COVID-19 patients. However, patients with cancer are $76 \%$ more likely to experience severe disease compared to those without cancer. This finding is consistent with a recent study which reported that the fatality of cancer patients infected with the Middle East respiratory syndrome (MERS)-CoV in 2012 was significantly higher compared to patients without cancers [31]. The greater likelihood of severe COVID-19 in patients with cancer may reflect their increased vulnerability to developing complications of respiratory viruses [32]. Moreover, many oncology patients often have additional risk factors for severe COVID19 , such as advanced age and presence of other comorbidities [32].

Our study highlights the need to implement extra precautionary measures (including an awareness campaign) to ensure that patients with cancer are not exposed to the virus during the current outbreak and future outbreaks. The development of a COVID-19 vaccine or treatment modality may also be useful towards reducing the risk of this vulnerable population. Furthermore, it is imperative that during the current COVID-19 outbreak, measures are implemented to minimise interruptions in the provision of essential medical services to cancer patients.

Of note, as expected given the observational nature of the data, there was evidence of high statistical heterogeneity in the pooled prevalence of cancer. This does not necessarily invalidate the findings. Further assessment revealed that the heterogeneity was not entirely explained by differences in age or gender distribution among study population. Also, while the included studies originated from a few countries, around half were conducted in China which may affect the generalisability of our findings. Hence, further analysis would be necessary as the COVID19 pandemic evolves and data from other regions become available. 


\section{Conclusion}

Our findings suggest that COVID-19 patients with cancer are more likely to experience severe disease than those without cancer. This emphasises the need to adopt additional precautionary measures to ensure that these vulnerable patients are not exposed to the virus, and if they become infected, extra attention should be provided to minimise their risk of adverse outcomes.

\section{Conflicts of interest}

None.

\section{Funding}

None.

\section{References}

1. The Center for Systems Sciences and Engineering, John Hopkins University Coronavirus COVID 19 Global cases [https://www.arcgis. com/apps/opsdashboard/index.html\#/bda7594740fd40299423467b48e9ecf6] Date accessed: 29/03/20

2. European Centre for Disease prevention and control (ECDC) (2020) Coronavirus disease 2019 (COVID-19) pandemic: increased transmission in the EU/EEA and the UK - seventh update [https://www.ecdc.europa.eu/sites/default/files/documents/RRA-seventhupdate-Outbreak-of-coronavirus-disease-COVID-19.pdf] Date accessed: 29/03/20

3. Desai A, Sachdeva S, and Parekh T, et al (2020) COVID-19 and cancer: lessons from a pooled meta-analysis JCO Glob Oncol 6 557-559 PMID: 32250659

4. Kalathil SG and Thanavala Y (2016) High immunosuppressive burden in cancer patients: a major hurdle for cancer immunotherapy Cancer Immunol Immunother 65(7) 813-819 https://doi.org/10.1007/s00262-016-1810-0 PMID: 26910314 PMCID: 5714319

5. Moher D, Liberati A, and Tetzlaff J, et al (2009) Preferred reporting items for systematic reviews and meta-analyses: the PRISMA statement PLoS Med 6(7) e1000097 https://doi.org/10.1371/journal.pmed.1000097 PMID: 19621072 PMCID: 2707599

6. Higgins JPT, Thomas J, and Chandler J, et al (editors) (2019) Cochrane Handbook for Systematic Reviews of Interventions version 6.0 (updated July 2019) Cochrane, 2019 [www.training.cochrane.org/handbook]

7. Liang W, Guan W, and Chen R, et al (2020) Cancer patients in SARS-CoV-2 infection: a nationwide analysis in China Lancet Oncol 21(3) 335-337 https://doi.org/10.1016/S1470-2045(20)30096-6 PMID: 32066541 PMCID: 7159000

8. Wells GA, Shea B, and O'Connell D, et al (2012) The Newcastle-Ottawa Scale (NOS) for assessing the quality of nonrandomized studies in meta-analyses [http://www.ohri.ca/programs/clinical_epidemiology/oxford.asp]

9. Nyaga VN, Arbyn M, and Aerts M (2014) Metaprop: a Stata command to perform meta-analysis of binomial data Arch Public Health 72(1) 39 eCollection 2014 https://doi.org/10.1186/2049-3258-72-39 PMID: 25810908 PMCID: 4373114 
10. COVID-19 National Emergency Response Center, Epidemiology and Case Management Team, Korea Centers for Disease Control and Prevention (2020) Early Epidemiological and Clinical Characteristics of 28 Cases of Coronavirus Disease in South Korea Osong Public Health Res Perspect 11(1) 8-14 https://doi.org/10.24171/j.phrp.2020.11.1.03 PMID: 32149037 PMCID: 7045878

11. ICNARC report on COVID-19 in critical care 27 March 2020 [https://www.icnarc.org/About/Latest-News/2020/03/27/Report-On775-Patients-Critically-III-With-Covid-19] Date accessed: 27/03/20

12. Wu J, Liu J, and Zhao X, et al (2020) Clinical characteristics of imported cases of COVID-19 in Jiangsu Province: a multicenter descriptive study Clin Infect Dis pii: ciaa199 https://doi.org/10.1093/cid/ciaa199

13. The Novel Coronavirus Pneumonia Emergency Response Epidemiology Team (2020) Vital Surveillances: The Epidemiological Characteristics of an Outbreak of 2019 Novel Coronavirus Diseases (COVID-19) - China, 2020 China CDC Weekly 2(8) 113-122

14. Zhu W, Xie K, and Lu H, et al (2020) Initial clinical features of suspected coronavirus disease 2019 in two emergency departments outside of Hubei, China J Med Virol https://doi.org/10.1002/jmv.25763

15. Sun Y, Koh V, Marimuthu K, et al (2020) Epidemiological and clinical predictors of COVID-19 Clin Infect Dis https://doi.org/10.1093/cid/ ciaa322

16. Chen T, Wu T, et al (2020) Clinical characteristics of 113 deceased patients with coronavirus disease 2019: retrospective study BMJ 368 m1091 https://doi.org/10.1136/bmj.m1091 PMID: 32217556 PMCID: 7190011

17. Guo T, Fan Y, and Chen M, et al (2020) Cardiovascular implications of fatal outcomes of patients with coronavirus disease 2019 (COVID19) JAMA Cardiol https://doi.org/10.1001/jamacardio.2020.1017 PMCID: 7101506

18. McMichael TM, Currie DW, and Clark S, et al (2020) Epidemiology of Covid-19 in a long-term care facility in King County, Washington N Engl J Med https://doi.org/10.1056/NEJMoa2005412 PMID: 32220208 PMCID: 7121761

19. Gupta N, Agrawal S, and Ish P, et al (2020) Clinical and epidemiologic profile of the initial COVID-19 patients at a tertiary care centre in India Monaldi Arch Chest Dis 90(1) https://doi.org/10.4081/monaldi.2020.1294

20. Klopfenstein T, Kadiane-Oussou NJ, and Toko L, et al (2020) Features of anosmia in COVID-19 Med Mal Infect pii:S0399-077X(20)30110-4 [doi:10.1016/j.medmal.2020.04.006]

21. Richardson S, Hirsch JS, and Narasimhan M, et al (2020) Presenting characteristics, comorbidities, and outcomes among 5700 patients hospitalized with COVID-19 in the New York City Area JAMA https://doi.org/10.1001/jama.2020.6775 PMID: 32320003 PMCID: 7177629

22. Pan L, Mu M, and Yang P, et al (2020) Clinical characteristics of COVID-19 patients with digestive symptoms in Hubei, China: a descriptive, cross-sectional, multicenter study Am J Gastroenterol 115 https://doi.org/10.14309/ajg.0000000000000620 PMID: 32287140 PMCID: 7172492

23. Pongpirul WA, Mott JA, and Woodring JV, et al (2020) Clinical characteristics of patients hospitalized with coronavirus disease, Thailand Emerg Infect Dis 26(7) https://doi.org/10.3201/eid2607.200598 PMID: 32267826

24. Feng Y, Ling Y, and Bai T, et al (2020) COVID-19 with different severity: a multi-center study of clinical features Am J Respir Crit Care Med https://doi.org/10.1164/rccm.202002-04450C PMID: 32275452

25. Yu J, Ouyang W, and Chua MLK, et al (2020) SARS-CoV-2 transmission in patients with cancer at a Tertiary Care Hospital in Wuhan, China JAMA Oncol https://doi.org/10.1001/jamaoncol.2020.0980 PMID: 32211820 PMCID: 7097836

26. Graselli G, Zangrillo A, and Zanella A, et al (2020) Baseline characteristics and outcomes of 1591 patients infected with SARSCoV-2 admitted to ICUs of the Lombardy Region, Italy JAMA https://doi.org/10.1001/jama.2020.5394 
27. Wang $\mathrm{L}$, Li X, and Chen $\mathrm{H}$, et al (2020) Coronavirus disease 19 infection does not result in acute kidney injury: an analysis of 116 hospitalized patients from Wuhan, China Am J Nephrol 1-6 https://doi.org/10.1159/000507471

28. Chu Y, Li T, and Fang Q, et al (2020) Clinical characteristics and imaging manifestations of the 2019 novel coronavirus disease (COVID19): a multi-center study in Wenzhou city, Zhejiang, China J Infect https://doi.org/10.1016/j.jinf.2020.03.023 PMID: 32360498 PMCID: 7194653

29. Tomlins J, Hamilton F, and Gunning S, et al (2020) Clinical features of 95 sequential hospitalised patients with novel coronavirus 2019 disease (COVID-19), the first UK cohort J Infect https://doi.org/10.1016/j.jinf.2020.04.020

30. Jazieh AR, Alenazi TH, and Alhejazi A, et al (2020) Outcome of oncology patients infected with coronavirus JCO Glob Oncol $6471-475$ https://doi.org/10.1200/GO.20.00064 PMID: 32196389 PMCID: 7124938

31. Hicks KL, Chemaly RF, and Kontoyiannis DP (2003) Common community respiratory viruses in patients with cancer: more than just "common colds" Cancer 97(10) 2576-2587 https://doi.org/10.1002/cncr.11353 PMID: 12733157

32. Weinkove R, McQuilten Z, and Adler J, et al (2020) Managing haematology and oncology patients during the COVID-19 pandemic: interim consensus guidance Med J Aust [https://www.mja.com.au/journal/2020/212/10/managing-haematology-and-oncologypatients-during-covid-19-pandemic-interim] 


\section{Supplementary material}

Table S1. Search strategy.

\begin{tabular}{|rl|}
\hline 1 & COVID-19.mp. \\
2 & COVID-19.m_titl. \\
3 & 2019 novel coronavirus.mp. \\
4 & 2019 novel coronavirus.m_titl. \\
5 & 2019 -nCoV.mp. \\
6 & 2019 -nCoV.m_titl. \\
7 & SARS-CoV-2.m_titl. \\
8 & SARS-CoV-2.m_titl. \\
9 & 1 or 2 or 3 or 4 or 5 or 6 or 7 or 8 \\
10 & comorbidities.mp. or Comorbidity/ \\
11 & comorbidity.mp. \\
12 & clinical characteristics.mp. \\
13 & clinical characteristics.m_titl. \\
14 & epidemiological.mp. \\
15 & epidemiolog*.mp. or Epidemiology/ \\
16 & epidemiological.m_titl. \\
17 & epidemiological.mp. \\
18 & 10 or 11 or 12 or 13 or 14 or 15 or 16 or 17 \\
19 & 9 and 18
\end{tabular}

Table S2. Institutional websites of some of the countries searched.

\begin{tabular}{|l|l|l|}
\hline Country & Institution & Website \\
\hline Global & World Health Organization & $\underline{\text { https://www.who.int/ }}$ \\
\hline USA & $\begin{array}{l}\text { Centers for Disease Control } \\
\text { and Prevention }\end{array}$ & $\underline{\text { https://www.cdc.gov/ }}$ \\
\hline China & $\begin{array}{l}\text { Chinese Centre for Disease } \\
\text { Control and Prevention }\end{array}$ & http://www.chinacdc.cn/en/ \\
\hline Spain & $\begin{array}{l}\text { National Centre of Epidemiol- } \\
\text { ogy, Institute of Health Carlos III }\end{array}$ & https://www.isciii.es/Paginas/Inicio.aspx \\
\hline Germany & $\begin{array}{l}\text { Robert Koch Institute (RKI) } \\
\text { France }\end{array}$ & https://www.rki.de/EN/Home/homepage_node.html \\
\hline Iran & $\begin{array}{l}\text { Ministry of Health and Medical } \\
\text { Education }\end{array}$ & $\underline{\text { http://www.behdasht.gov.ir/ }}$ \\
\hline UK & Public Health England & https://www.gov.uk/government/organisations/public-health-england \\
\hline Switzerland & Federal Office of Public Health & https://www.bag.admin.ch/bag/en/home.html \\
\hline The Netherlands & $\begin{array}{l}\text { National Institute of Public } \\
\text { Health and the Environment }\end{array}$ & $\underline{\text { https://www.rivm.nl/en }}$ \\
\hline Canada & Public Health Agency of Canada & https://www.canada.ca/en/public-health.html \\
\hline
\end{tabular}

